\title{
ARCHEOLOGIE MLÝNŮ ZANIKLÝCH VE DRUHÉ POLOVINĚ 20. STOLETÍ
}

KLíčovÁ SLOva: vodní mlýn, archeologie, středověk, novověk, 19. a 20. století

KEYwords: watermill, archaeology, Late Middle Ages, modern history, 19th and 20th centuries

\section{ÚvoD}

$\mathrm{V}$ posledních několika letech se předmětem nedestruktivního archeologického výzkumu a výjimečně též archeologického odkryvu stávají stavby zaniklé $\mathrm{v}$ důsledku poválečných událostí (jedním z prvních drobných příspěvků: Vařeka a kol. 2008: 101-117; Galusová 2010: 280-302). Doposud zachovalé nadzemní pozůstatky pocházejí nejčastěji z 18 . století až počátku 20. století (obr. 5). Zástavba takovéto parcely však může být o mnoho starší. Novějším příkladem takovéhoto bádání jsou odkryvy Mašova a Francova mlýna prováděné od roku 2008 v regionu Tachov v západních Čechách (Galusová 2009: 67-79; 2015a: 65-79; Galusová, Maříková 2016: 493-505). V souvislosti s těmito výzkumy je třeba zmínit též záchranný archeologický odkryv vodního mlýna Touchořiny čp. 40, zvaného Hutmühle, prováděný od roku 2011 u Ústí nad Labem v severozápadních Čechách (Galusová 2015a: $81-95)^{1}$.

\footnotetext{
${ }^{1}$ Př́spěvek vznikl za podpory grantu SGS-2014-046 nazvaného Čtvrtá etapa archeologického výzkumu vodního mlýna Touchořiny čp. 40.
} 


\section{ARCHEOLOGIE VODNíCH MLÝNŮ}

\section{Metody odkryvu}

Poloha sond byla zvolena s ohledem na narušení reliktů a záměry výzkumu. Mezi hlavní badatelské otázky náležely kontinuita stavby, stavební etapy a mlecí technologie. Na základě terénní prospekce a znalostí vnitřního členění stavby se sítí sond pokryly především mlýnice a síň, tedy prostory, kde se očekávaly artefakty řešící cíle výzkumu. Archeologický odkryv se dále zaměřil zahloubené prostory. Pokud to výzkum umožnil, byly veškeré kamenné relikty v průběhu exkavace ponechány ve své původní poloze, a to nejenom z důvodu možnosti následného uchopení celkového kontextu stavby a interpretace jednotlivých prostor, ale také z hlediska ochrany památky.

\section{Archeologický odkryv Mašova mlýna (Tachov, Žebráky)}

Relikty Mášova mlýna leží $9 \mathrm{~km}$ jihozápadně od Tachova, přibližně $1 \mathrm{~km}$ západně od obce Žebráky (obr. 1), na katastru již zaniklé obce Pořejov, v okresu Tachov.

První zjištěná písemná zmínka pochází z poloviny 17. století (Galusová 2009: 76). Po roce 1908 došlo $\mathrm{k}$ přestavbě objektu $\mathrm{z}$ důvodu ničivého požáru. Objekt byl vystavěn z lomového kamene a cihel na maltu. V síni vznikla velká chlebová pec, která zabírala až jednu čtvrtinu místnosti. Seznam a mapa vodních děl republiky Československé mlýn uvádí pouze v mapové př́iloze a nikoli ve vlastních seznamech (Seznam a mapa... 1932a, sešit 5: 39). Jednalo se tedy o vodní dílo do 2 koňských sil (tamtéž: 3 ). V mapě je mlýn označen kroužkem severně od obce Žebráky na potoku Stegbach. Ve druhé polovině 20. století stavba zchátrala a zanikla.

V červenci roku 2008 a srpnu roku 2010 zde proběhly dvě etapy archeologického odkryvu. Výzkum byl proveden studenty Západočeské univerzity, Filozofické fakulty, katedry archeologie. Jednalo se o odkryv na potenciálně ohrožené lokalitě, která byla v době výzkumu užívána k pastevním účelům. Přestože archeologický odkryv mlýniště porušil a z větší části vytěžil, výsledky výzkumu budou využity pro následnou prezentaci tohoto typu objektů a povedou k prevenci a ochraně obdobných staveb.

Na lokalitě vzniklo 10 sond (obr. 2). Tři se nalézaly mimo interiér objektu. Současný povrch terénu v obytných prostorách výzkum zachytil v úrovni 587,7 m n. $\mathrm{m}$.

Ačkoliv výzkumy z let 2008 a 2010 přinesly značné množství keramického materiálu (celkem 1887 fragmentů), z větší části (81\%) se jednalo o druhotně přemístěné, již znehodnocené zboží. Lze tak soudit na základě jeho uložení v reliktu soklu pece pod SJ 102. V této poloze sloužila keramika spolu se struskou a křemeny jako tepelná izolace. Materiál byl získán zejména 

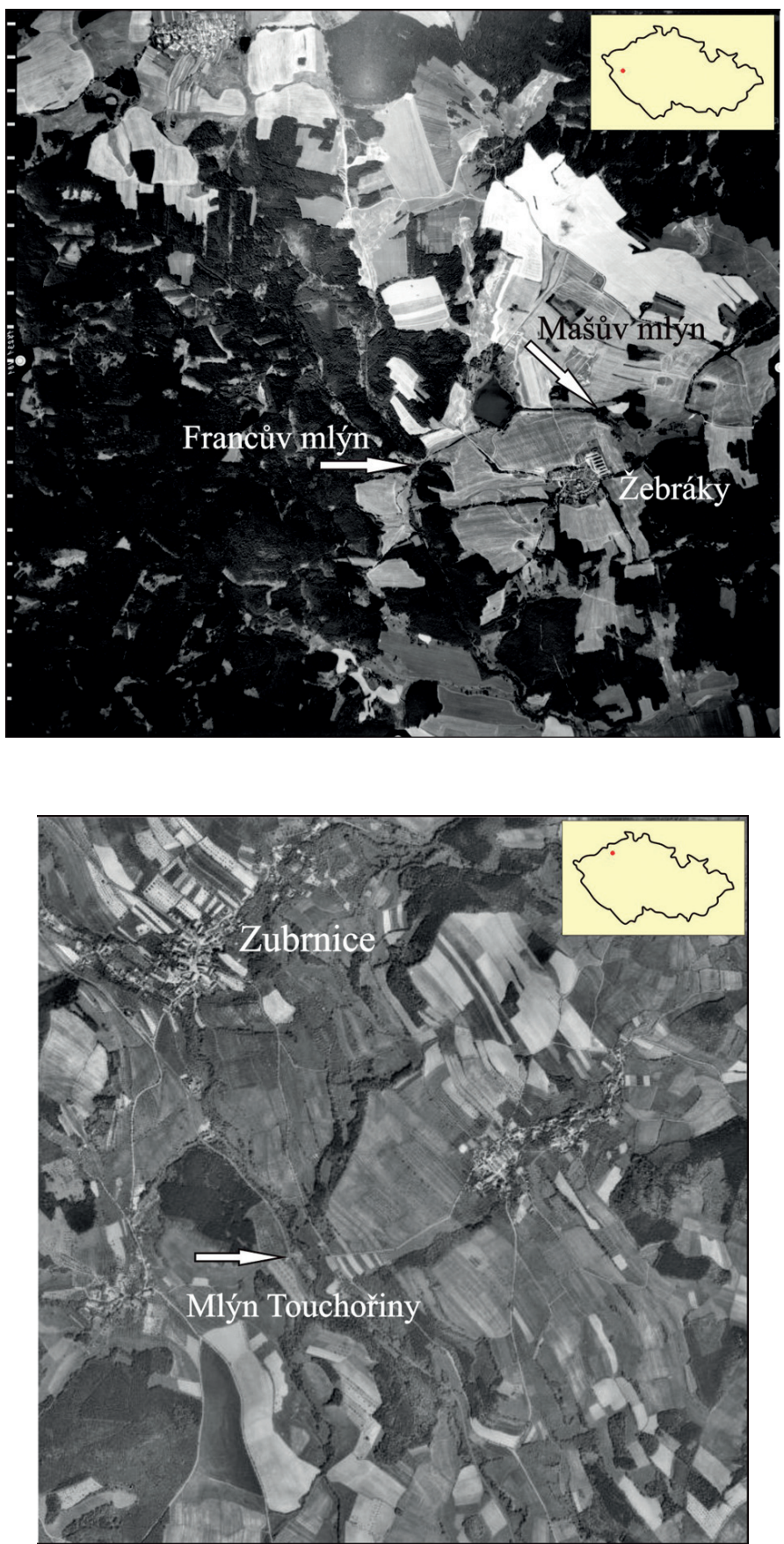

Obr. 1. Poloha lokalit na výřezu leteckých měřických snímků pořízených v průběhu 1. Poloviny 20. století (digitalizace L. Galusová). 


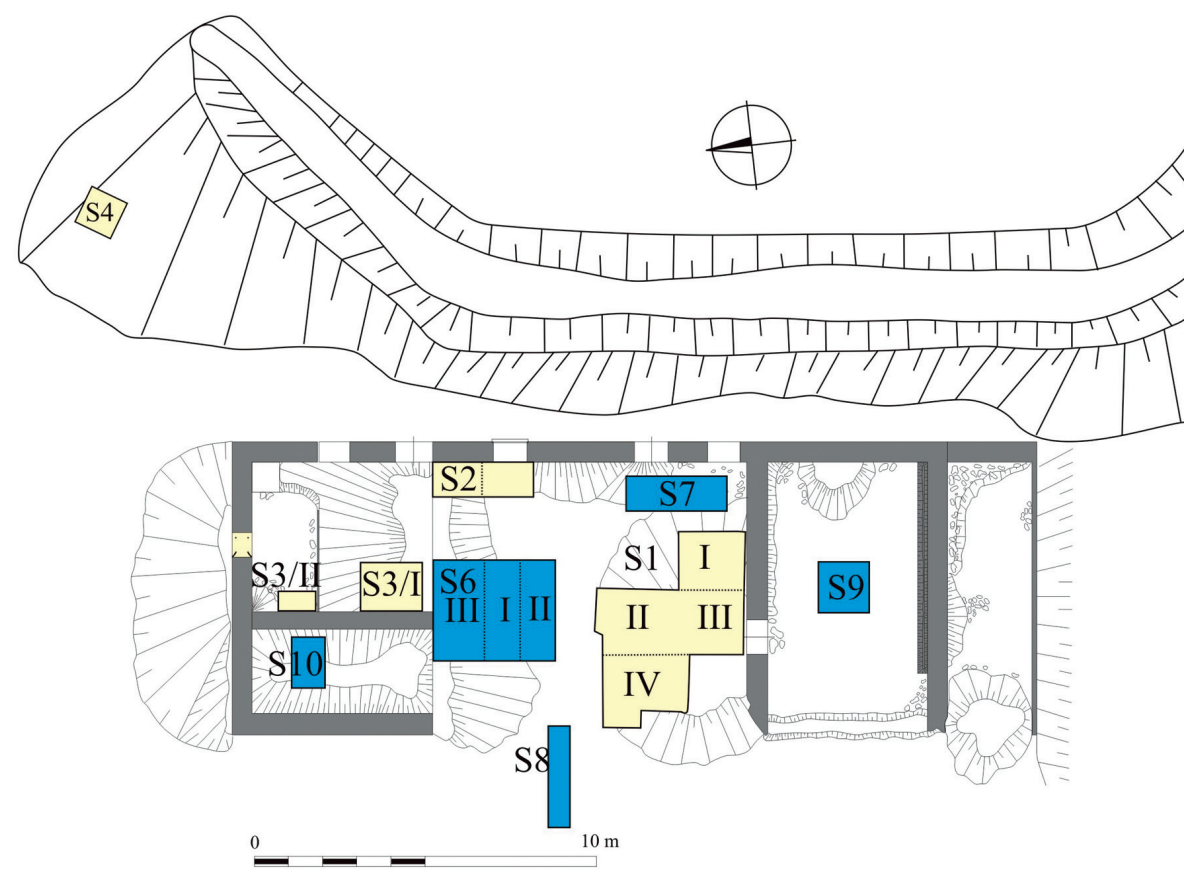

S5

Obr. 2. Mašův mlýn (okres Tachov, katastrální území Žebráky). Schéma objektu s vytýčenou sondáží. Odkryv z roku 2008 vyznačen červeně, z roku 2011 vyznačen modře

(digitalizace L. Galusová).

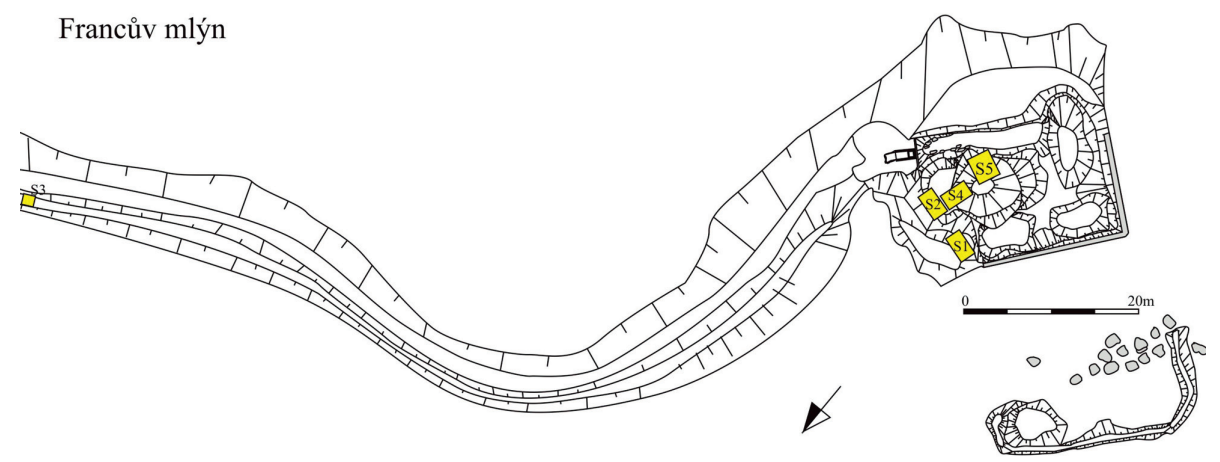

Obr. 3. Francův mlýn (okres Tachov, katastrální území Žebráky). Schéma objektu s vytýčenou sondáží (digitalizace L. Galusová). 
z vrstvy 103, poté spíše výjimečně z vrstev 105, 107, 601, 603 a 607 . Všechny tyto jednotky zde stavebníci deponovali nejspíše někdy kolem počátku 20. století, v době přestavby objektu. Početná keramická kolekce (1535 úlomků) tak pochází z průběhu 19. století. Jedná se o oxidační, tvrdě pálené zboží, na lomu ostré, se středně zrnnou frakcí se zrny výjimečně nad $2 \mathrm{~mm}$, nejčastěji s vnitřní glazurou různých barev a odstínů od žluté, po hnědou, oranžovou, mléčnou, tmavě hnědou až černou i zelenou. Výjimečně se vyskytly i fragmenty $\mathrm{s}$ bílým až červeným nástřepím, polévané transparentní glazurou. Dále se vyskytla výzdoba červenou hlinkou, vlysy či výzdoba plastickou páskou na podhrdlí a kachle.

Keramické fragmenty ze starších horizontů jsou početně podstatně méně zastoupeny (40), přičemž z větší části pocházejí opět ze sond 1 a 6 (32). Z tohoto počtu pouze několik fragmentů obsahuje chronologicky citlivé prvky, dle nichž lze datovat nejstarší stavební fázi vodního mlýna. Jedná se opět o oxidační, tvrdě pálené zboží z vrstev 111, 114 a 629, na lomu ostré, avšak s jemnější frakcí, nejčastěji s vnitřní glazurou světlých hnědo žlutých, výjimečně zelených tónů, př́padně s červeným či bílým nástřepím a podglazurní výmalbou bílou či zelenou glazurou, př́padně zdobené vegetabilními motivy žlutou, červenou a zelenou podglazurní výmalbou či hlinkou s překrytím transparentní glazurou. Tyto fragmenty hrnčiny lze řadit na základě úlomku glazované mísy s talířovitým podokrajím, výzdoby mísy a okrajových profilací nejpozději do průběhu 17. století (Vařeka 2010: 172-173).

Dle písemných pramenů byl vodní mlýn předběžně datován do průběhu první poloviny 17. století. Na základě archeologických nálezů lze tuto dataci akceptovat. Na zjištění stáří objektu se nejvýznamněji podílela sonda 1, především sektory II a III.

Archeologickým výzkumem byly zjištěny 3 stavební fáze objektu (obr. 6 , $7,8)$.

\section{První stavební fáze: průběh první poloviny 17. století až přelom 18. a 19. sto- letí}

Mlýn vznikl v průběhu první poloviny 17. století a jeho přestavba je kladena do přelomu 18. a 19. století. Zásadním nálezem v tomto ohledu se stala konstrukce skládaná ze sbíraných kamenů místní provenience (K121) interpretovaná jako podezdívka, zděná na jíl. Fragment zdi se orientoval od severu k jihu, souběžně se současnou nádvorní zdí, od níž byl vzdálen 2,3 metru východně. Šírka této konstrukce dosahovala $0,50 \mathrm{~m}$ o mocnosti přibližně $0,50 \mathrm{~m}$. Celkovou délku se bohužel nepodařilo určit. Od východu přisedala na korunu zdiva jílovitá ulehlá vrstva 122 , která s ní víceméně výškově korelovala. $\mathrm{Z}$ archeologické situace a charakteru vrstvy lze odvozovat, že se jedná o o nejstarší podlahu vodního mlýna. Na základě těchto zjištění lze předpokládat, že stavba 


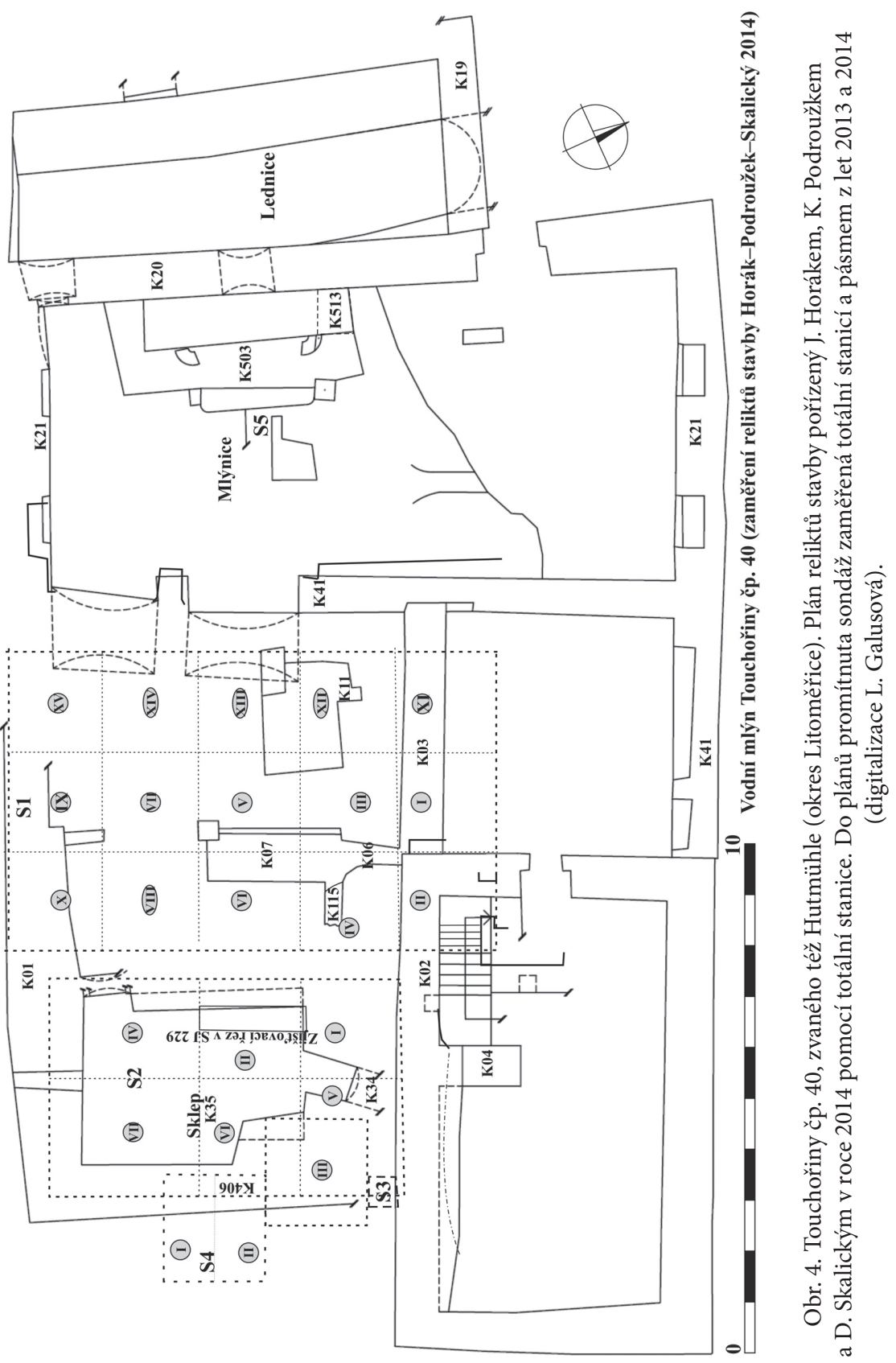



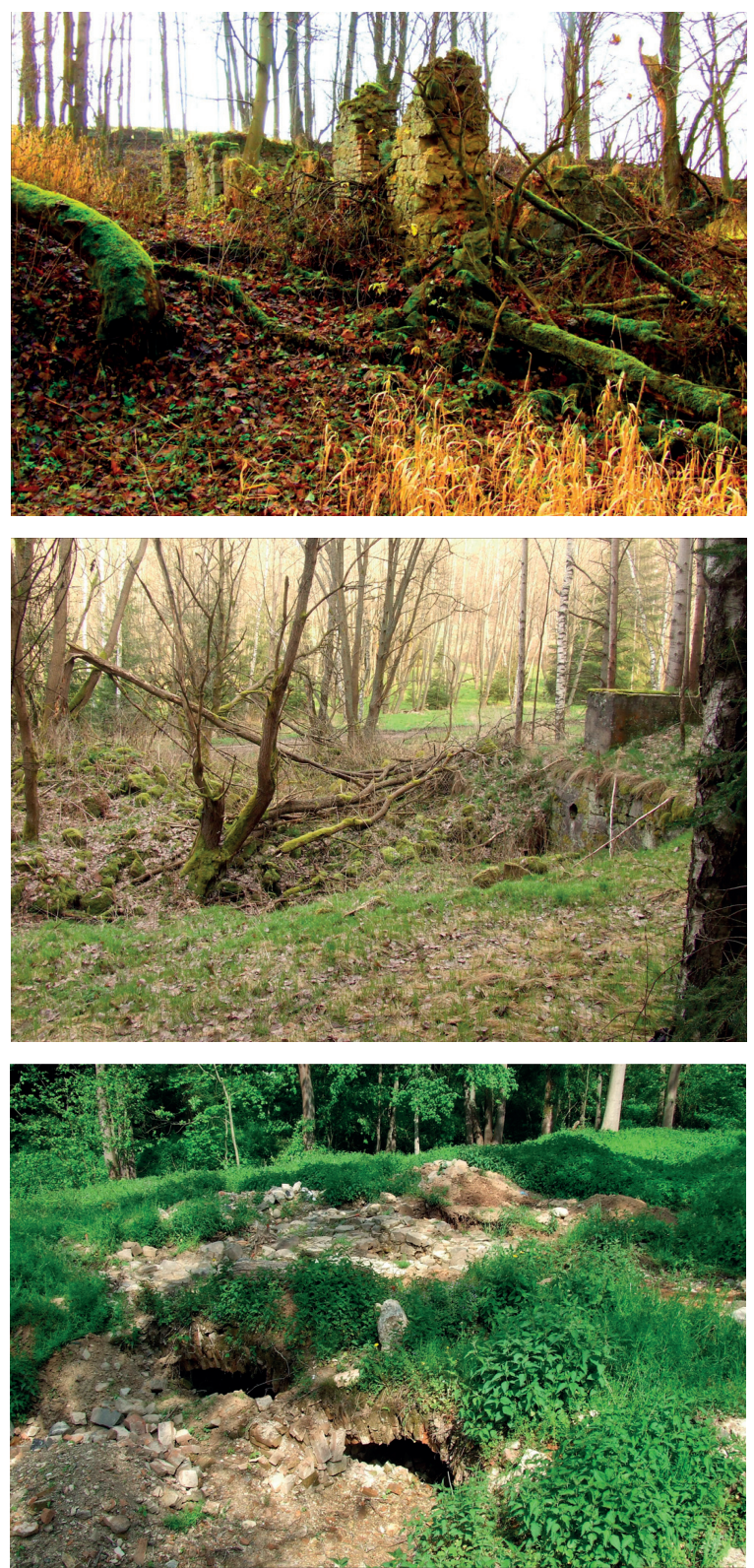

Obr. 5. Celkové pohledy na pozůstatky staveb vodních mlýnů. Vlevo nahoře Mašův mlýn, pohled od severu, v popředí mlýnice. Vpravo nahoře Francův mlýn, pohled od jihovýchodu, v pravé části betonová kašna na turbínu a relikty mlýnice. Konvexní útvar v levé části skrývá zbytky nejmladšího topeniště (okres Tachov). Dolní fotografie přibližuje pozůstatky touchořinského mlýna, pohled od západu. $\mathrm{V}$ popředí mlýnice, $\mathrm{v}$ pozadí síň (okres Litoměřice)

(foto L. Galusová 2008 - Mašův a Francův mlýn a 2012 - Touchořiny). 
byla užší, situovaná východním směrem. Již v této epoše vznikl objekt na trojdílném půdorysu o šíri $6,5 \mathrm{~m}$. Jeho délka nebyla jasně definována. Minimální rozměr objektu však nejspiše činil 15 až $18 \mathrm{~m}$. V severovýchodním koutu (sonda 2) výzkum zachytil objekt hruškovitého tvaru o hloubce $0,68 \mathrm{~m}$ a maximální šířce $0,32 \mathrm{~m}$, který lze interpretovat jako starou, již nepoužívanou zásobní jámu. Zásobnice jsou nalézány v síních domů i z průběhu novověku (Vařeka 2004: 194, 195-196, 199). Lze tedy předpokládat, že severní část velké středové prostory sloužila jako sín, z níž se vstupovalo do mlýnice. Do jižní části velké středové prostory by bylo tedy logické situovat světnici a dále $\mathrm{k}$ jihu komoru. Tato hypotéza má však několik nedostatků. Ve 20. století se stal vodní mlýn prokazatelně domem chlévního typu (k tématu blíže např. Vojtíšek, Vařeka 1999: 29) a vyvstává tedy otázka, zda tento charakter stavba měla i v průběhu novověku. Sonda 9 prokázala, že dlažba v prostoru současného chléva musela být položena již před druhou etapou přestavby. Tento závěr vychází z absence jakékoli starší podlahy či dlažby $\mathrm{v}$ tomto prostoru a především $\mathrm{z}$ důvodu shody souvztažnosti úrovně nejstarší stratigrafické jednotky 122 a konstrukce K121 s tímto dlážděním (SJ 906). Na tomto základě se lze domnívat, že SJ 906 byla položena již v době založení objektu. Hrubší forma dláždění napovídá, že místnost sloužila k jiným než obytným účelům, nevykazuje však žádné prvky typické pro chlévní provoz (kanálek pro odtok močoviny, apod.). To však samožrejmě neznamená, že zde nebyl chlév, jelikož sonda 9 byla pro takovéto závěry př́liš malá. $\mathrm{V}$ této souvislosti si lze představit spíše variantu chlévního domu s vloženou komorou (např. Vojtíšek, Vařeka 1999: 29), popřípadě šalandou a s obytným polopatrem.

$\mathrm{Na}$ základě sondáže $\mathrm{v}$ technické prostoře byla potvrzena funkce mlýna zlomkem mlecího kamene, ležáku. Odkryv dále prokázal minimálně dvě stavební fáze návodní zdi (K304a, K304b). Drobný keramický fragment na podloží nemůže sice přesvědčivě datovat počátky provozu mlýna, jeho existence je však prokázána písemnými prameny již z průběhu 17. století. Podoba nejstarší fáze mlýnice není zřejmá. Na základě dalšího vývoje a vzhledu návodní zdi se lze pouze domnívat, že tato část stavby mohla být do přelomu 18. a 19. století roubená.

\section{Druhá stavební fáze: průběh 19. století až počátek 20. století}

Druhá fáze objektu byla spojena s jeho rozšířením západním směrem (do dvora), $\mathrm{v}$ průběhu 19. století, čímž mlýn získal téměř shodné rozměry 8,7 x $21 \mathrm{~m}$. Datace této stavební epochy byla provedena na základě několika keramických fragmentů získaných z vyrovnávacích zásypů, vytvářených jako lože pro jmenované podlahy a dlažby při přestavbě. Ve středové prostoře $\mathrm{v}$ této fázi vznikla jedlová podlaha s prkny o šírí $20-30 \mathrm{~cm}$ a síle $2,5 \mathrm{~cm}$ (v jižní části se jednalo o SJ 111) a cihlová i kamenná dlažba (ve stř̌ední části se jednalo o SJ 
127 a 120). Severní část zaujímala pouze kamenná dlažba (SJ 609, 610 a 621) vážící se na relikt kamenné podezdívky (K639), která oddělovala síň (na severu) od světnice či šalandy (v jižní části). Vstup do objektu z nádvorní strany tak $\mathrm{v}$ této době musel být při mlýnici (na severní straně). Tuto část stavby však archeologický výzkum nepostihl. V sondě 1, sektoru II a IV ve vrstvách 118 a 119 byly nalezeny zlomky komorových kachlů polévaných tmavě zelenou glazurou spolu s kusy mazanic. Jednalo se o požárovou destrukci z počátku 20. století (zvrstvení viz obr. 9). Ačkoli samotné novověké topeniště výzkum nepostihl, lze jej předpokládat v zadní části síně, při západním okraji sondy 2. Velmi marginálně se kuchyňský provoz projevil ve východním profilu sondy 6 vyšší frekvencí zlomků novověké keramiky z vrstev 620,628 a 630. Současně $\mathrm{v}$ této epoše $\mathrm{v}$ obytné prostoře fungovala kachlová kamna, která byla umístěna nejspíše na cihlové podestě (SJ 127). Zásobnice se nacházela za černou kuchyní a patrně se užívala ještě v této době. Sporé artefakty (získané ze dna zásobnice) však tuto hypotézu nemohou potvrdit. Tento předpoklad tak vychází především ze skutečnosti, že nad zásobnicí ležely pouze pozůstatky požárových vrstev (SJ 207). Ze stovek kusů mazanic s otisky kuláčủ lze soudit, že sín̆ a světnice (či šalanda) v této fázi výstavby byly roubené. Naopak mlýnice již v průběhu 19. století sestávala z kamene, tak jako jižní prostora (současný chlév).

\section{Třetí stavebni fáze: průběh 20. století}

Po požáru (na počátku 20. století) byl mlýn vystavěn Josefem Krausem (tehdejším majitelem) na shodných základech, tentokráte však z cihel a kamene. Jednalo se o lomový kámen místního původu, př́padně sbíraný kámen. $\mathrm{V}$ této době se již skutečně jedná o chlévní dům, o síle zdiva $0,60 \mathrm{~m}$ s rozměry 8,7 x 21 m, který byl vybaven velkou chlebovou pecí. Toto nové topeniště však vzniklo bez vazby na svého předchůdce v jihozápadní části středové prostory. Na destrukci z požáru vyvstala chlebová pec. Vlastní jádro pece (SJ 102) stálo na přibližně $1 \mathrm{~m}$ vysokém soklu (K106). Po zbudování soklu z druhotně užitého materiálu (přeživšího požár), byl do jeho nitra deponován materiál tvořený zlomky keramických fragmentů, vysokopecní a kovářskou struskou i úlomky křemene. V tomto období lze jednoznačně definovat síň s kamennou dlažbou a s navazující pecí v jihozápadním rohu obytné prostory i s úzkým průchodem za pecí (SJ 112). Později v průběhu první poloviny 20. století byla zbudována moderní kuchyn̆ se sporákem. V sondě 1,6 a 7 se z této doby podařilo odkrýt moderní cihlové přičky, které kuchyň ohraničily a světnici rozdělily víceméně na pravidelné obdélníky. V severovýchodním rohu výzkum odhalil prkennou podlahu (SJ 202) zánikového horizontu, která výškově korelovala s kuchyňskou dlažbou (SJ 108). V nádvorní zdi mlýna při středové prostoře se vyrýsoval komunikační otvor s př́mým vstupem do kuchyně SJ 108 (dlažba kuchyně) a SJ 128 (cihlový práh). Zlomky technologie nejčastěji pocházejí z období 19. 
až 20. století. Jedná se o fragment jahelky, mlecího kamene, pozůstatek lopatovitého čepu hř́́dele se třemi zděřemi a kovová transmise s řemenicí na klínový řemen.

Vodní mlýn byl vybaven obyčejným mlecím složením, na jehož paleční kolo se napojovala také jahelka a nejspíše též př́ležitostně i stroj na výrobu perlet'ových knoflíků. Až do svého zániku mlýn využíval archaický vodní pohon.

\section{Archeologický odkryv Francova mlýna (Tachov, Žebráky)}

Francův mlýn leží na Kateřinském potoce 9 km jihozápadně od Tachova v západních Čechách. Pozůstatky stavby mlýna na horní vodu trojdílné dispozice se rozkládají na ploše 8,9 x 24 m. Reliéfní tvar objektu lze charakterizovat jako silně zvlněný $\mathrm{s}$ centrálním konvexním útvarem $\mathrm{v}$ jeho středové části o průměru 5-6 $\mathrm{m}$ a výšce až $1,5 \mathrm{~m}$.

První písemná zmínka se váže $\mathrm{k}$ roku 1555 , kdy mlýn vlastní v dědičné držbě mlynáŕ Hans Hyschner (Galusová 2009: 37-39). Na konci 19. století byl mlýn významně přestavěn. Mlýnská živnost byla provozována do druhé světové války (Gabler 1993: 89-90). Objekt zanikl ve druhé polovině 20. století.

Archeologický odkryv vodního mlýna proběhl v červenci roku 2011 (obr. 10). Výzkum se uskutečnil z důvodu narušení pozemkové parcely č. 55/1 těžbou dřevin, na které mlýn stával. Odkryv se soustředil na centrální část objektu, kde se očekávalo topeniště. Sondáž částečně zasáhla i mlýnici. Bylo položeno 5 sond (obr. 3). Sondy 1, 2 a 4 (v mlýnici) byly vyměřeny o ploše 2 x $3 \mathrm{~m}$, sonda 3 (v náhonu) dosáhla plochy $1 \times 1 \mathrm{~m}$ a sonda 5 o dvou sektorech (v centrální části objektu) byla vyměřena o celkové ploše 6 × 2,8 m.

Výzkumem bylo nalezeno 259 fragmentı̊ keramického materiálu. Nejvíce úlomků hrnčiny se získalo z vrstev 207 (19\%) a 502 (27\%). Informace ke stavebnímu vývoji obsahovaly pouze sondy 2 a 5 , částečně i sonda 4 . V sondě 2 , ve vrstvách 201, 203, 205, 207 a 211 bylo zjištěno celkem 120 keramických úlomků (téměř $50 \%$ z celého souboru. Ze sondy 5 se získalo celkem 79 fragmentů, což je $32 \%$ z celé keramické kolekce a sonda 4 odhalila celkem 39 úlomků keramiky ( $15 \%$ ze souboru).

Keramické fragmenty jsou typologicky i technologicky velmi blízké keramické kolekci z nedalekého Mašova mlýna. Významným datovacím prvkem zde opět byly okrajové profilace a výzdoba glazovaných talířù, případně mís $\mathrm{s}$ talířovitým podkrajím. Dle analogie z Mašova mlýna lze mladší horizont z vrstvy 207, 402 a 502 datovat nejspíše do konce 18. století až průběhu 19. století. Uloženinu s fragmenty keramiky s chronologicky citlivějšími znaky, je možné zařadit do průběhu 17. století (obr. 6). Okrajové profilace lze komparovat $\mathrm{s}$ raně novověkými profilacemi z Mašova mlýna, ale především s keramikou ze západočeské vsi Vojkov (Vařeka 2010: 159, obr. 6: 7, 9, 17, 37). Jedná se opět o oxidační, tvrdě pálené zboží na lomu ostré, s jemnou frakcí se zrny pouze 


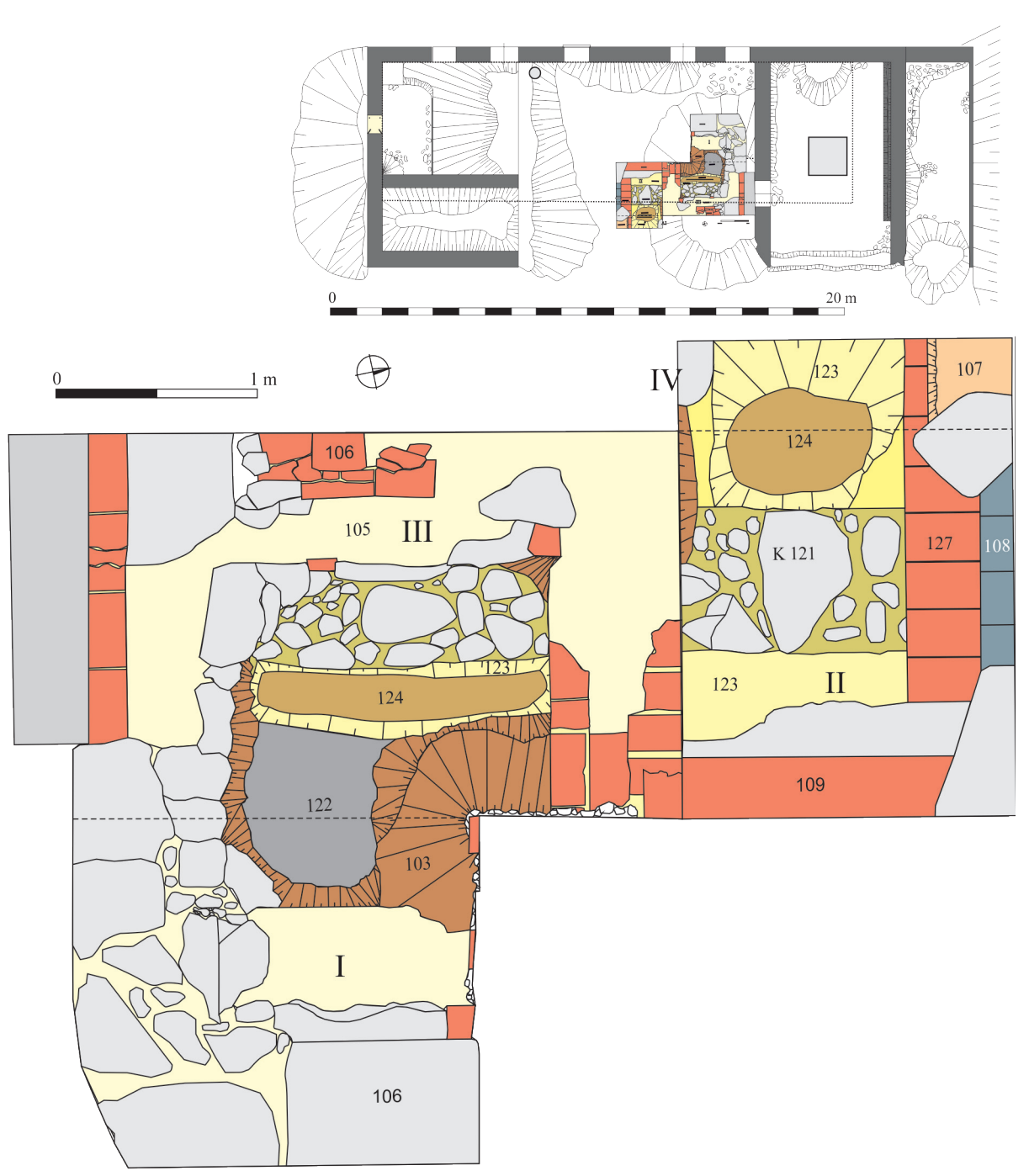

Obr. 6. Mašův mlýn (okres Tachov). Sonda 1, sektor I, II, III a část sektoru IV. Plán zachycuje nejstarší konstrukci K121 (sektor II a III). Současně je na plánu patrná hliněná podlaha (SJ 122), která se nalézala v interiéru domu. V horní ćásti obrázku je sondáž zasazena do kontextu mlýnského díla. Datace: polovina 17. století až 18./19. století (digitalizace L. Galusová). 


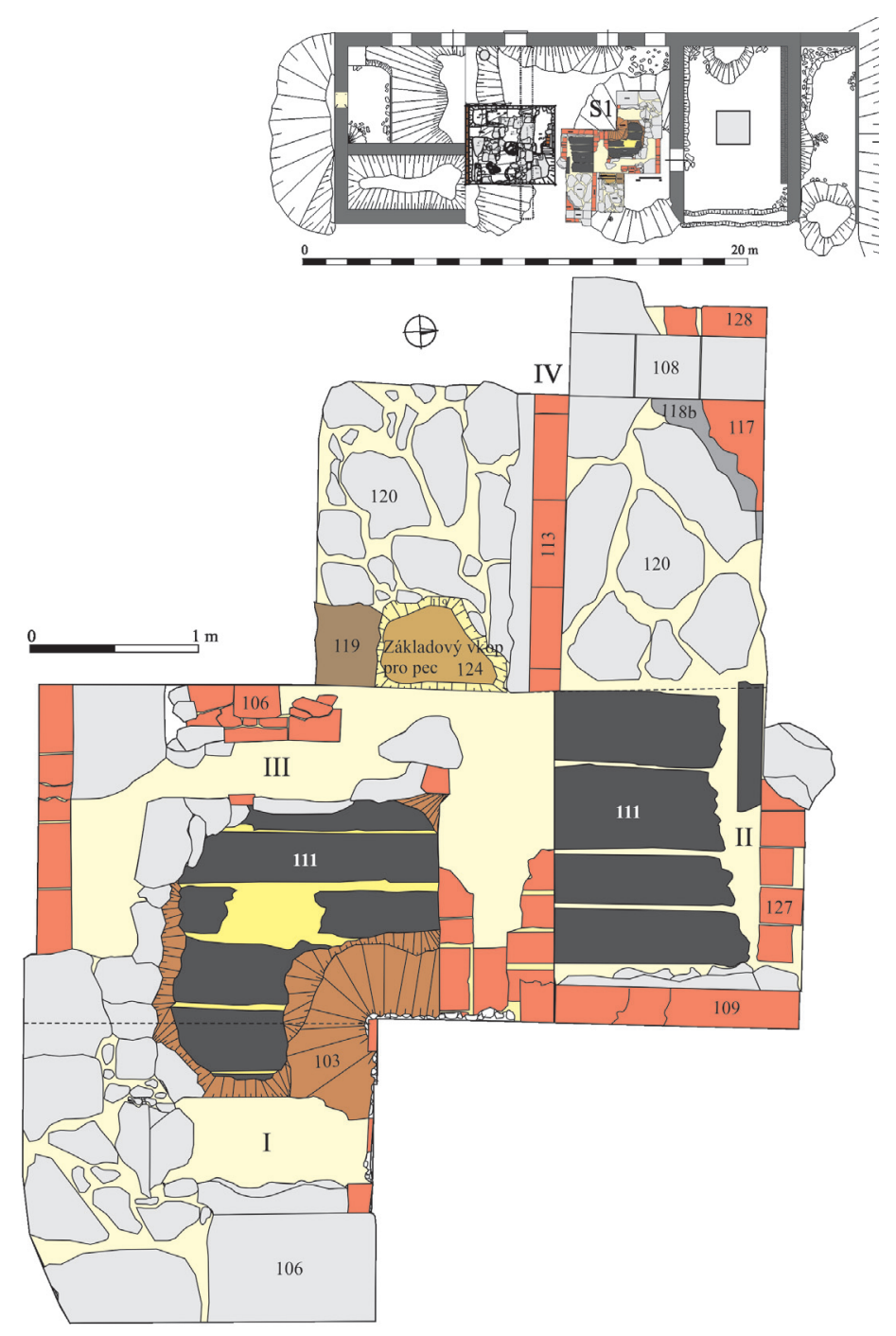

Obr. 7. Mašův mlýn (okres Tachov). Sonda 1, sektor I, II, III a IV. Plán zachycuje dlažby v sektoru II a IV (SJ 120, SJ 127) a spálenou dřevěnou podlahu v sektoru III a II (SJ 111). V sektoru III je patrný relikt chlebové pece (K106). Na plánu je zachycena též dlažba (SJ 108) a práh (SJ 128), které však náležejí do nejmladší stavební fáze objektu. V horní části obrázku je sondáž zasazena do kontextu vodního mlýna. Datace: průběh 19. století až počátek 20. století, kdy objekt zanikl požárem (digitalizace L. Galusová). 

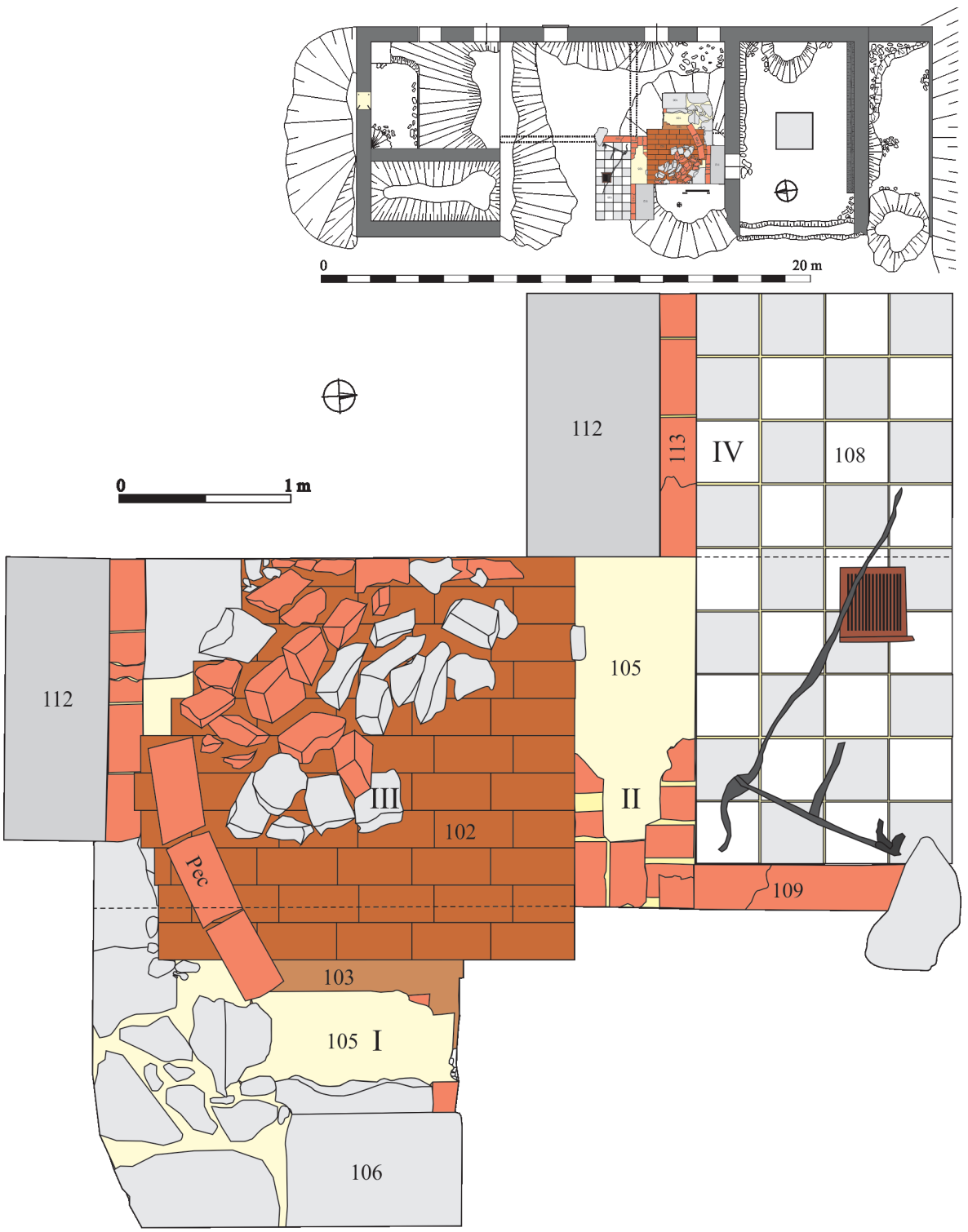

Obr. 8. Mašův mlýn (okres Tachov). S 1, sektor I, II, III a IV. Plán zachycuje relikt chlebové pece. Pozůstatek pece (SJ 106). Jádro pece (SJ 102). Dále je patrná cihlová př́čka (K109) a moderní kuchyňská dlažba se zachovalou částí kamenného sporáku a roštu (dlažba SJ 108). V horní části obrázku je sondáž zasazena do kontextu vodního mlýna. Datace: počátek 20. století až do zániku stavby (digitalizace L. Galusová). 
výjimečně nad $1 \mathrm{~mm} \mathrm{~s}$ vnitřní glazurou světlých hnědo žlutých, výjimečně zelených tónů, případně s červeným, hnědočerveným či bílým nástřepím a podglazurní výmalbou bílou či zelenou glazurou.

Zajímavě situaci doplňuje nález stěny komorového kachle s několika fragmenty hrnčiny z těla nádoby, nejpravděpodobněji hrnce světle hnědě glazované se třemi fragmenty mazanice. Keramika se materiálově nevymyká již zmíněným nálezům. Úlomek kachle je vyrobený ze světlé hrubší hrnčiny, tvrdě pálený, na lomu ostrý. Hmota obsahuje jen výjimečně i zrna o velikosti do $2 \mathrm{~mm}$. Na stěně kachle jsou stopy po pojivu. Neglazovaný úlomek, tak jako zlomky hrnčiny z vrstvy 518 zapadají do konceptu raně novověké datace polohy vodního mlýna v tomto prostoru (př́loha 1).

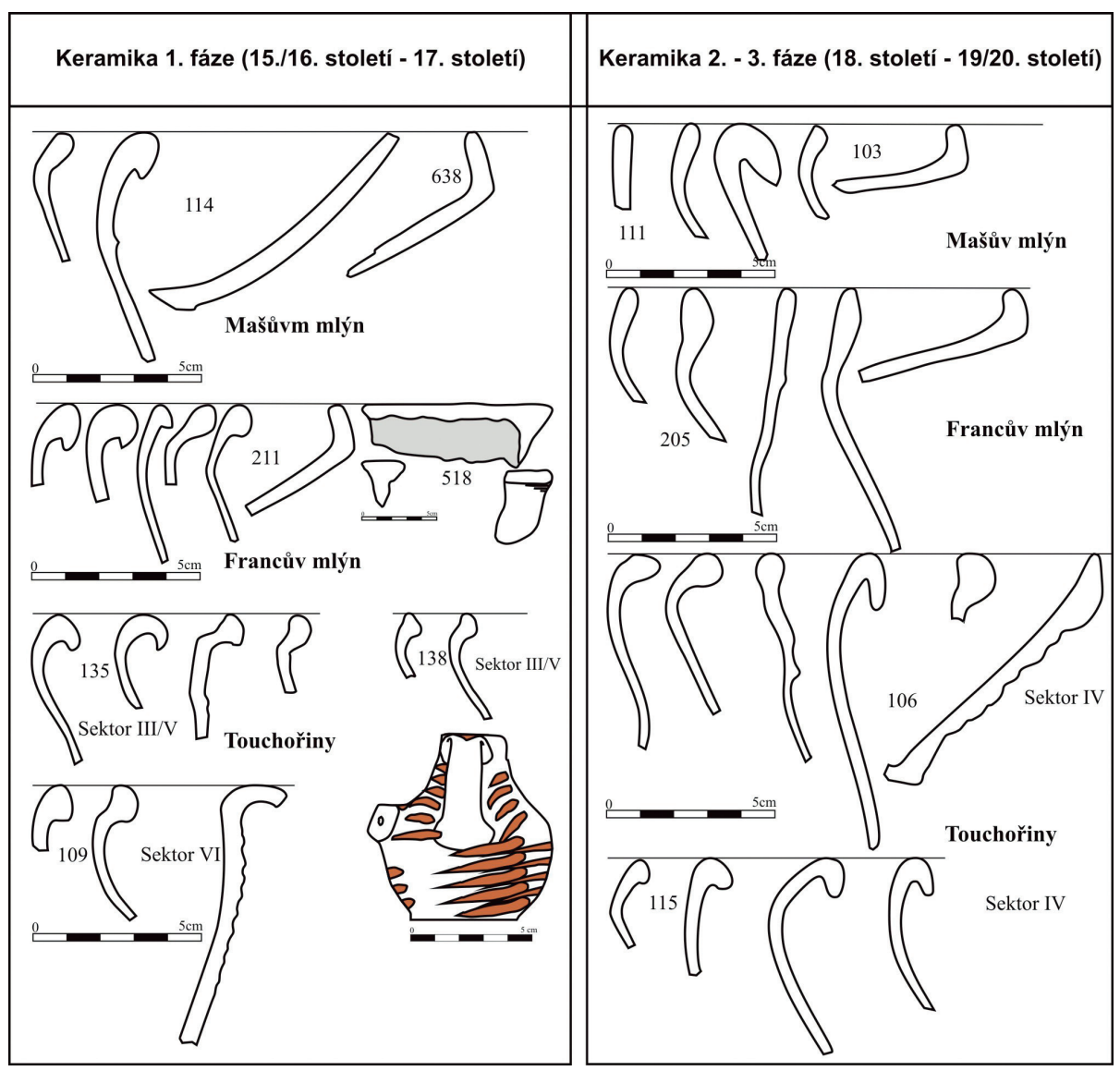

Př́loha 1. Vybrané fragmenty keramiky, 1. fáze, (15./16. století-17. století), jedná se o hrnce, mísu s talířovitým podokrajím, kachel, malá konvička (digitalizace L. Galusová). 2.-3. fáze, (18.-19. /20. století), jedná se o pekáč, hrnce, talíře, pánve (digitalizace L. Galusová). 
Dle výsledků archeologických odkryvů lze soudit, že zkoumané mlýniště bylo zastavěno až v průběhu raného novověku, a to nejpozději v průběhu druhé poloviny 16 . století či v průběhu 17 . století. V souvislosti s písemnými prameny lze uvažovat o zde stojícím mlýnu již v první polovině 16. století. Archeologické nálezy to však jednoznačně nepotvrdily. Nejpozději na konci 17. století stavba vodního mlýna stála v současné poloze o shodné orientaci.

Na základě archeologických a etnografiekých analogií (viz Galusová, Mař́ková 2015: 309-324) lze předpokládat, že mlýn byl nejspíše částečně či plně roubený na kamenné podezdívce. Tato tradice se mohla udržet až do průběhu 19. století (archeologicky je tato skutečnost jednoznačně podpořena pouze nálezy z blízkého Mašova mlýna). Dle archeologických zjištění lze předpokládat, že rozměry předchůdce $\mathrm{z}$ období $16 . ? / 17$. - až 1 . polovina 18 . století byly 18 x 6-7 m s uspořádáním mlýnice - sín + světnice - komora. $Z$ analogií (tamtéž) dále vyplývá, že již v raném novověku byla výstroj vodního mlýna složená z pohonu, převodů, hranice, mlecího a prosévacího ústrojí.

Nejpozději na počátku 19. století došlo k přestavbě objektu a rozšíření stavby. Objekt byl patrně již od svého založení $\mathrm{z}$ větši části či plně kamenný. Jižním směrem se na mlýn nejspíše vázala hospodářská stavba.

$\mathrm{V}$ průběhu 20. století došlo $\mathrm{k}$ výrazným stavebním úpravám v rámci modernizace mlýnských strojů s osazením objektu moderní Francisovou turbínou (u objektu zachovalá betonová kašna na turbinu) v průběhu první čtvrtině 20. století. Francův mlýn byl $\mathrm{v}$ této době již zajisté celokamenný a nejspíše dvoupodlažní. Lze se tak domnívat na základě mocnosti sutin v celé odkrývané ploše.

V objektu byla objevena opět pouze nejmladší fáze topeniště (viz obr. 11) (shodná situace byla odkryta i v blízkém Mašově mlýně). $V$ souvislosti s jeho výstavbou patrně došlo ke změně komunikačního schématu a zániku staršího topeniště, jehož umístění nebylo na základě archeologického odkryvu spolehlivě určeno.

Zázemí mlýna nebylo zkoumáno. V terénu jsou dodnes patrné relikty rybníku, náhona zakončeného při mlýně reliktem betonové kašny na turbínu.

Mlýn zanikl v průběhu třetí čtvrtiny 20. století, byl zbourán těžkou technikou.

\section{Archeologický záchranný odkryv mlýna Touchořiny čp. 40 (Hutmühle)}

Vodní mlýn Hutmühle leží na Lučním potoce $13 \mathrm{~km}$ východně od Ústí nad Labem v severozápadních Čechách.

Archivní průzkum lokality provedl M. Ebel (Ebel 2010). Nejstarší písemná zpráva o mlýnu pochází z roku 1636. Mlýn sloužil svému účelu ještě v roce 1930 (Seznam a mapa... 1932b, sešit 10: 31). Zanikl ve druhé polovině 20. století. Historie objektu již byla detailně publikována (Galusová 2015a: 83-84).

V roce 2011 se pozornost zaměřila na prostor východně od mlýnice, kde výzkumný tým očekával relevantní situace k vývoji stavby a zjištovacím odkryvem 
stanovil minimální přítomnost sutin. Zde vznikla sonda 1 o patnácti sektorech o rozměru 10 x $6 \mathrm{~m}$, odkrývaná postupně v šachovnicové síti. V roce 2012 došlo k rozšîř̌ení sondáže východním směrem. Sondu 2 o dvou sektorech, kdy každý měřil 2 × 2 m, archeologický tým umístil do prostoru sklepa. Odkryv byl veden po přirozených stratigrafických jednotkách v celé ploše sondy. V roce 2014 se provedla v sondě 2 (sektoru II) zjištovací sondáž, která v úrovni $1,8 \mathrm{~m}$ pod současným povrchem terénu narazila na hliněnou podlahu sklepa bez relevantních archeologických nálezů. Jelikož odkryv v interiéru sklepa odhalil pouze destrukční vrstvy 20. století, které vznikly při likvidaci lokality, bylo rozhodnuto o rozšíření sondy na konečných 4 × $7 \mathrm{~m}$ (vnitřní velikost sklepa) s jeho celkovým vyčištěním těžkou technikou. Následně došlo ke zdokumentování zahloubené prostory, jejího zapažení a začištění. Výzkum tak podchytil celý interiér zahloubené místnosti a její vztah $\mathrm{k}$ další konstrukcím. V roce 2012 vznikl východně od sondy 2 další sektor o rozměru 2 x 2 m, který měl řešit umístění východní štítové zdi mlýna. Tento výkop se však musel uzavř́t již v hloubce $0,53 \mathrm{~m}$ z důvodu prezence značného množství destrukce, jíž nebylo možné danými prostředky exkavovat. Jižně od této sondy v roce 2014 vznikla sonda 3 a 4 , která měla řešit shodnou problematiku jako sonda 2, sektor III. Sonda označená pořadovým číslem 3 byla pouze zjišt'ovacím výkopem podél konstrukce K02 o rozměru $0,5 \times 0,5 \mathrm{~m}$ a sledovala napojení předpokládané konstrukce východní štítové zdi ke K02. Sonda 4 dosáhla standardního rozměru 2 × 2 m a měla sledovat ve vhodnější poloze průběh zdiva východní štítové konstrukce. V roce 2013 a 2014 probíhal paralelně s výše zmíněnou sondáží též odkryv technických prostor bagrem s fotografickou dokumentací. Po skrývce značné části sutin těžkou mechanizací byla zbývající vrstva destrukce o mocnosti $0,4-0,5 \mathrm{~m}$ exkavována ručně, aby nedošlo k porušení zbytků případné technologie, ležící na dně mlýnice. Technická prostora svými zdmi tvořila sondu 5 (obr. 4).

Výzkumem bylo získáno celkem 2436 fragmentů hrnčiny. Detailně byly doposud zpracovány pouze keramické fragmenty ze sondy 1 , přičemž se doposud podařilo analyzovat 1389 zlomků z celkového počtu 1476 . Významné počty keramiky byly zjištěny v sektoru IV (739), dále v sektoru XIII (157) a III (271) a posléze $\mathrm{v}$ sektorech VI (159), V (51) a VII (45). Z analyzovaných střepů představovaly atypické fragmenty 1031 kusů. Z typických zlomků bylo možné odlišit 25 kusů podhrdlí, 136 okrajů nádob, 40 pokliček, 27 uch a 101 dno nádob. Některé fragmenty keramiky měly plastickou výzdobu či malbu. Plastická výzdoba uvnitř nádob se zjistila ve třiceti př́ípadech a na povrchu keramických střepů se objevila 181 krát. Malovaná keramika se vyskytla u 221 fragmentů, přičemž 11 jich obsahovalo vnitřní malbu a u 209 kusů se malba objevila na povrchu. Glazurou bylo vybaveno 418 střepů. $V$ př́padě neglazovaných zlomků se jednalo o 958 kusů, tvrdě oxidačně pálených, převážně malovaných červenou hlinkou, př́ípadně zdobených rytím rádélkem. Z neglazovaných kusů se vyčlenilo 71 okrajů, 39 


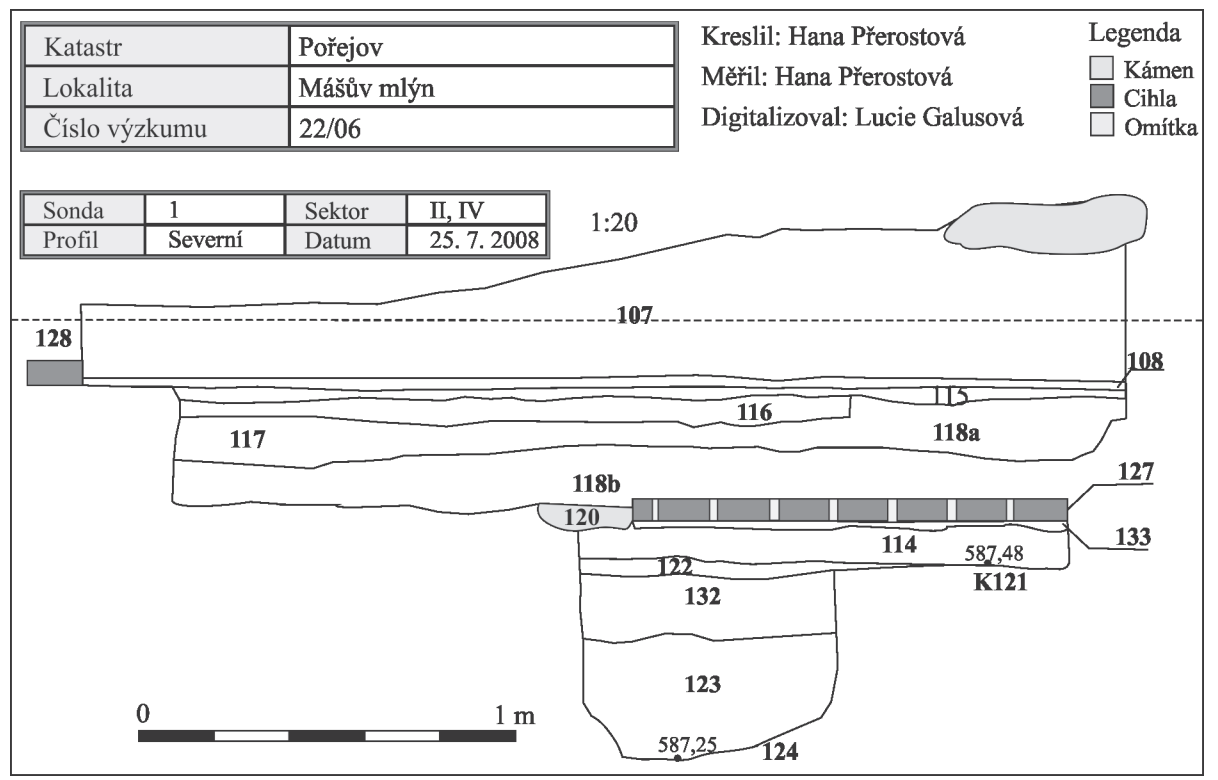

Obr. 9. Mašův mlýn (okres Tachov). Sonda 1 , sektor II a IV, severní profil. Na řezu je patrný fragment dlažby (SJ 120), na níž ležely vrstvy 117 až 119 (digitalizace L. Galusová).

pokliček, 15 uch a 63 dna nádob. Keramická hmota těchto fragmentů obsahovala středně zrnný materiál. Tato keramika se objevila v sektoru VI a v sektorech IV, III a V. V sektoru VI byly zjištěny mladší fragmenty nádob z 19. a 20. století pouze ve vrstvě 102 , která ležela téměř na povrchu. Tento mladší materiál se do jmenované jednotky mohl dostat náhodně při likvidaci stavby. Níže uložené vrstvy 104, 108 a 109 již obsahovaly pouze neglazované fragmenty s červeně malovanými vzory vlnek a vlnic i linií. $Z$ těchto artefaktů se vyčlenily hrnce s uchy a pokličkami, dále jeden pohár, kahan a mísa.

Za typologicky nejzajímavější artefakt lze označit oxidačně pálenou miniaturní konvičku světlé, žlutohnědé barvy s páskovým uchem a trubicovitou výlevkou, jejíž osa je kolmá k ose ucha. Drobné páskové prožlabené ucho vyrůstá z okraje na tělo nádobky. Konvička je zdobena červeným malováním, které lze ztotožnit s výzdobnými motivy středověkého severočeského keramického okruhu. Část hrdla a trubicovitá výlevka byly v minulosti odlomeny. Rozměry nádobky činí $72 \times 68 \mathrm{~mm}$, přičemž průměr dna dosahuje $35 \mathrm{~mm}$ a průměr okraje činí $50 \mathrm{~mm}$. Na základě charakteru keramického materiálu, výpalu a výzdoby lze předpokládat, že se jedná o domácí keramickou produkci z blízkých levínských dílen. Dle kontextu, analogií a provedené analýzy 
potravinových zbytků na dně nádoby lze dále předpokládat, že konvička z touchořinského mlýna je malou pozdně středověkou kojeneckou lahví (Galusová 2016: 57-67).

Většinu neglazovaného materiálu dle morfologických a typologických znaků v komparaci s keramickou sbírkou muzea Ústí nad Labem lze řadit nejpozději do poloviny 15 . století.

Tvrdě oxidačně pálená hrnčina, na lomu ostrá, slabého jemně až středně zrnného střepu, polévaná nejčastěji uvnitř nádoby světle hnědou či žlutou glazurou či jejich kombinacemi, př́ípadně zdobená podglazurní žlutou či bílou malbou na hnědém podkladu se nalézala $\mathrm{v}$ sektorech IV (zejména $\mathrm{v}$ jednotce 106), III a V (zvláště vrstvy 135 a 138). Tento materiál dle morfologických a typologických znaků lze nejspíše řadit do druhé poloviny 16 . století až do průběhu 17. století.

Ve vrstvách 103, 122, 126 a 127 byly zjištěny oxidačně pálené drobné úlomky keramických fragmentů (nejčastěji pánve), často bez chronologicky citlivých znaků, na lomu ostré, stř̌edně zrnného střepu, polévané uvnitř i vně hnědou, žlutou, zelenou glazurou či jejich kombinacemi. Jedná se o zboží z 18.-19. století.

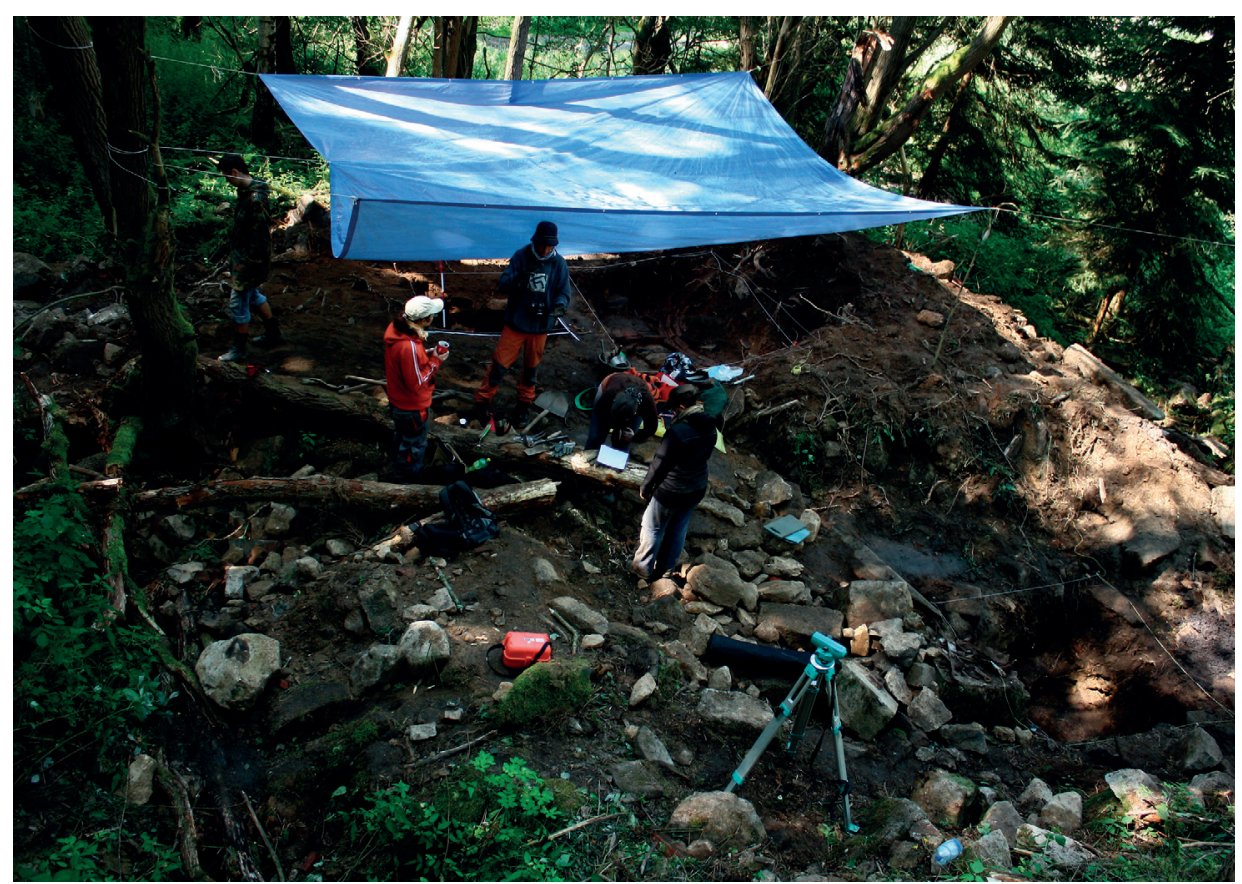

Obr. 10. Francův mlýn (okres Tachov). Pohled na mlýniště v době archeologického výzkumu. Fotografie pořízena od severu (od betonové kašny na turbínu) (foto L. Galusová 2011). 
Bělnina, polokamenina a porcelán reprezentující nejmladší horizont druhé poloviny 19. století až první poloviny 20. století byly nalezeny pouze výjimečně, nejčastěji př́mo na povrchu či v mocných destrukčních vrstvách z 20. století.

Mlýn Hutmühle (Touchořiny čp. 40) skrýval celkem deset zlomků mlecích kamenů a jedno celé složení. Jejich charakter a přibližné datování bylo již popsáno v př́spěvku Archeologický výzkum vodního mlýna Touchořiny čp. 40 (sezóna 2011-2014) (Galusová 2015a: 93-95).

Nejstarší aktivity na parcele jsou datovány pozdně středověkým souborem oxidačně pálené keramiky zdobené červenou hlinkou ze sondy 1, sektoru VI Z vrstev 104, 108 a 109 a částečně též ze sektoru IV vrstvami 104, 108. Většina zlomků ze jmenovaných stratigrafických jednotek pochází z přelomu 14. a 15. století až první poloviny 15. století. Vyjma zlomků mís jsou nejstarší fragmenty pouze drobnými úlomky se zaoblenými lomy. Charakter souboru, tak jako absence novověkých fragmentů $\mathrm{v}$ těchto vrstvách dokládá, že se jedná o drobné zachovalé intaktní souvrství, které nebylo odstraněno mladšími zásahy. Uložení stratigrafických jednotek lze klást do období kolem poloviny 15 . století. Stratigrafická jednotka 108 se př́mo vázala na konstrukci K115, která je tak nejstarším zdivem na lokalitě (Galusová 2015b: 276). Před odkrytím vstupního portálu sklepa $\mathrm{v}$ průběhu roku 2015 bylo předpokládáno, že sklepní konstrukce K35 mohla být vystavěna společně s dnes již rozrušenou K115, která byla interpretována jako pozdně středověký taras a společně tak tvořily nejstarší zástavbu na parcele (Galusová 2014: 90; 2015a: 89, obr. č. 9). Tento předpoklad se však odkrytím vstupního portálu a rozborem stratigrafických vztahů zdiva nepotvrdil. Konstrukce K115 tak zůstává nejstarším zdivem na parcele bez př́mé chronologické vazby na okolní konstrukce. $\mathrm{K}$ podobě objektu v této nejstarší fázi se tak bohužel nelze nikterak vyjádřit. Stavba sklepa a přestavba mlýnice vodního mlýna byly provedeny nejpozději roku 1636, kdy byl objekt rozššřen severním směrem (obr. 12). V této době byla K115 rozrušena a zasypána. V místech sondy 1 , sektoru III a zčásti též sektoru $\mathrm{V}$ byly provedeny terénní úpravy pro stavbu černé kuchyně a nad K115 vystavěna konstrukce K07 orientována sever-jih, která ji z větší části překryla (obr. 13). Nejstarší zed’ tak byla ponechána ,in-situ“ pouze v místech, kde nepřekážela novému provozu. Podél jižní zdi v interiéru objektu byl zahlouben vstup do sklepa. V prostoru mlýnice, respektive ve žlabu pro paleční kolo lze k této epoše vztáhnout vrstvu 507 a konstrukci K513 (Galusová 2015a: 88, obr. č. 7; 2015b: 278, obr. č. 5). Nejstarší jílovité utužené podlahy, zjištěné $\mathrm{v}$ prostoru sondy 1 sektoru VI a z části sektoru IV byly tedy již v průběhu 17. století odstraněny veškerými jmenovanými úpravami, jelikož nejstarší komunikační jednotky byly v síni tvořeny až novověkými dlažbami. Nejpozději v průběhu první poloviny 17. století mlýn nabyl trojdílného půdorysu, přičemž z jihu byl ohraničen konstrukcí K01 a od východu konstrukcí K406 respektive zdivem sklepa K35 (původně K36). Obé jsou jednou a touž 

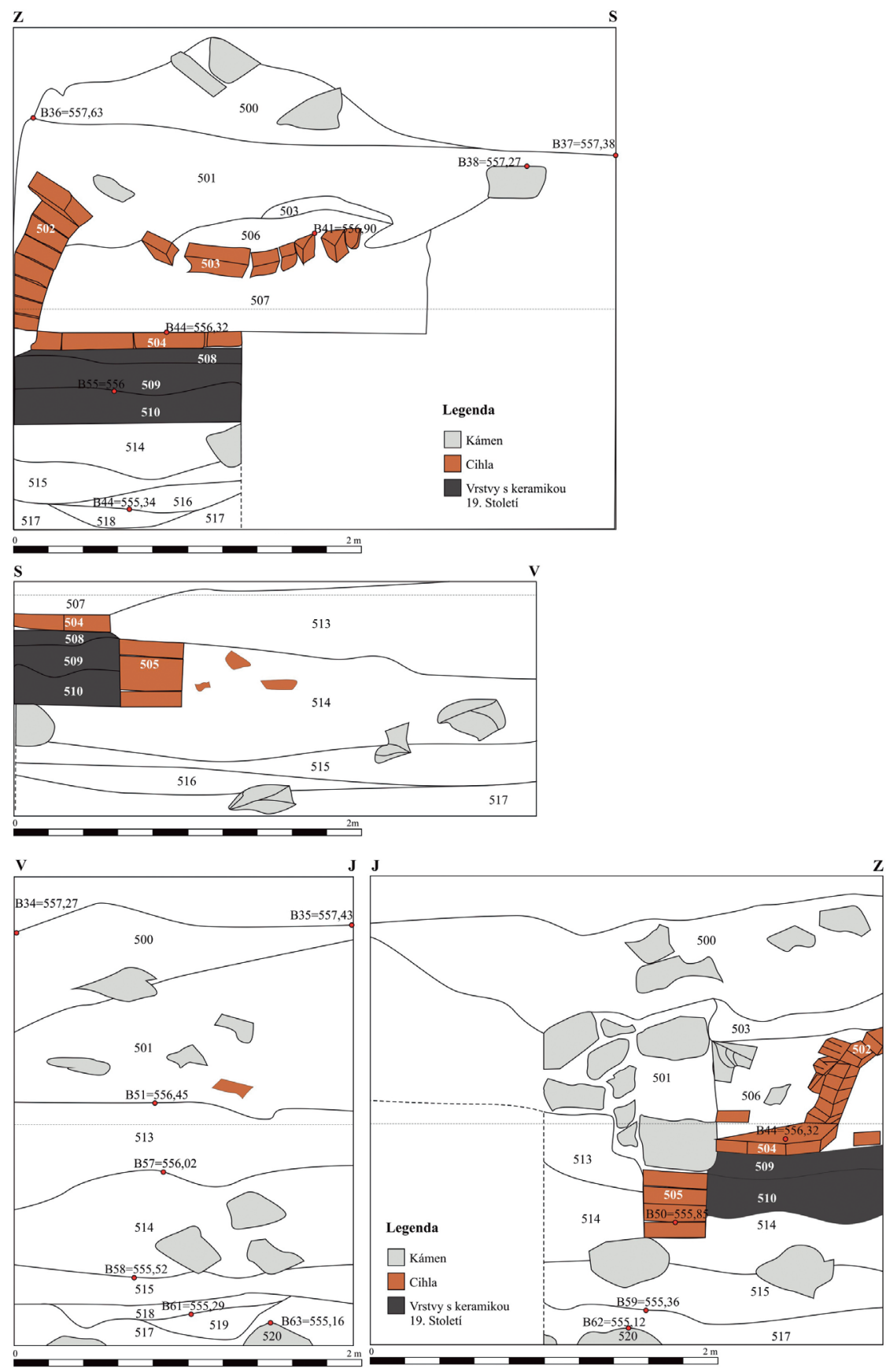

Obr. 11. Francův mlýn (okres Tachov). Sonda 5. Digitalizovaná kresebná dokumentace odhaleného topeniště (digitalizace L. Galusová). 


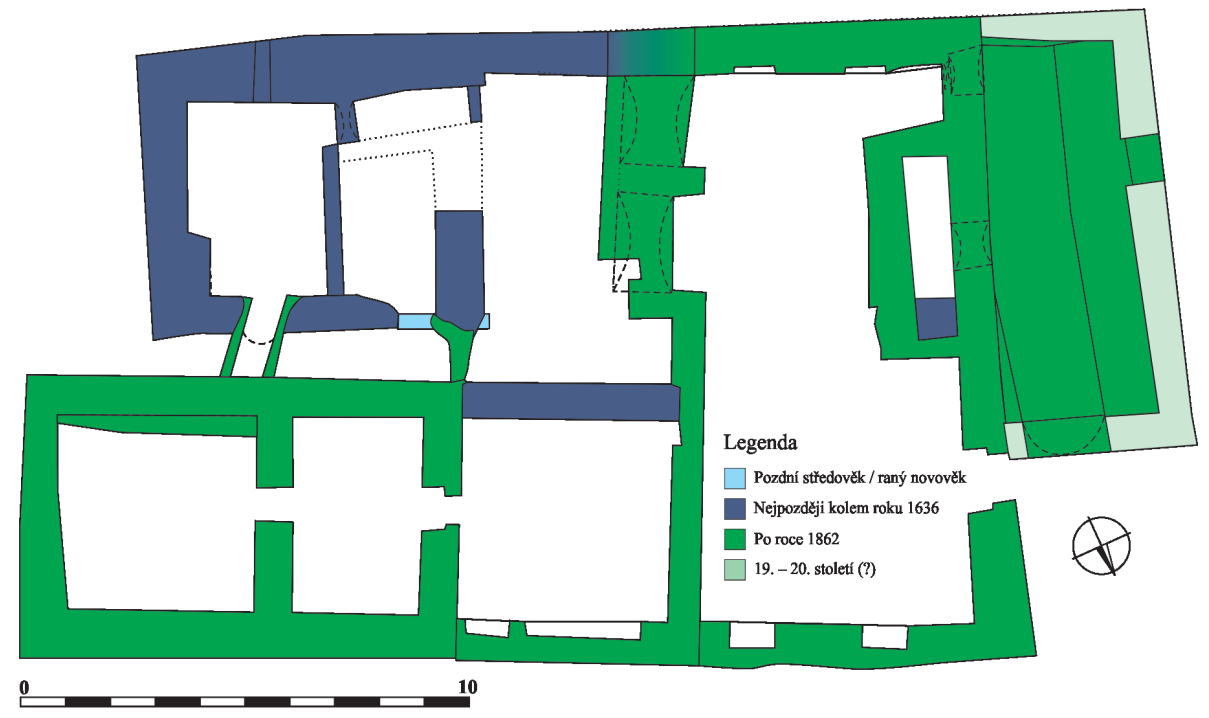

Obr. 12. Touchořiny čp. 40 (okres Litoměřice). Stavební vývoj vodního mlýna Touchořiny čp. 40 (tvorba L. Galusová 2015 na podkladech J. Horáka, K. Podroužka a D. Skalického).

konstrukcí, na níž stála snad roubená světnice. Ze severu byl mlýn vymezen konstrukcí K03 a patrně též konstrukcí K513 zjištěné ve žlabu pro paleční kolo. Zastavěná plocha mlýniště tak činila přibližně 8,3 x $18,5 \mathrm{~m}$. Sklep stavebníci vsadili do jílovitokamenitých potočních usazenin (SJ $123=422)$, které v určité úrovni přešly do fluviálních povodňových náplav hnědo-červené až červené barvy, obsahující drobné zaoblené křemenné klasty a vulkanity (SJ 229). Jedná se o druhý typ podloží, který se vyskytl taktéž ve žlabu pro paleční kolo (SJ 508). Zdi sklepa tedy stály na vrstvě 229 bez dalšího založení. Základová spára K35 se tak nalézala na povrchu stratigrafické jednotky 229. Drobné vrstvy ležící na povrchu SJ 229 lze interpretovat jako podlahu sklepa.

$\mathrm{Na}$ základě archeologických pramenů lze uvažovat o výstavbě severního př́stavku již v průběhu druhé poloviny 19. století. Jisté však je, že vznikl nejpozději před rokem 1924 (Galusová 2015a: 93-94, obr. 10). Výplň základového vkopu pro konstrukci K02 obsahoval především keramiku z průběhu novověku a jen výjimečně byly učiněny nálezy starších keramických fragmentů, které však vykazovaly prvky druhotného uložení (silné abraze, špatně čitelné stopy výzdoby červenou hlinkou apod.). Současně však vrstvy neobsahovaly téměř žádné zlomky mladší keramiky jako je bělnina, porcelán apod. Od roku 1862 získali mlýn manželé Winzenz a Katharina Tschernosterovi. V držení 


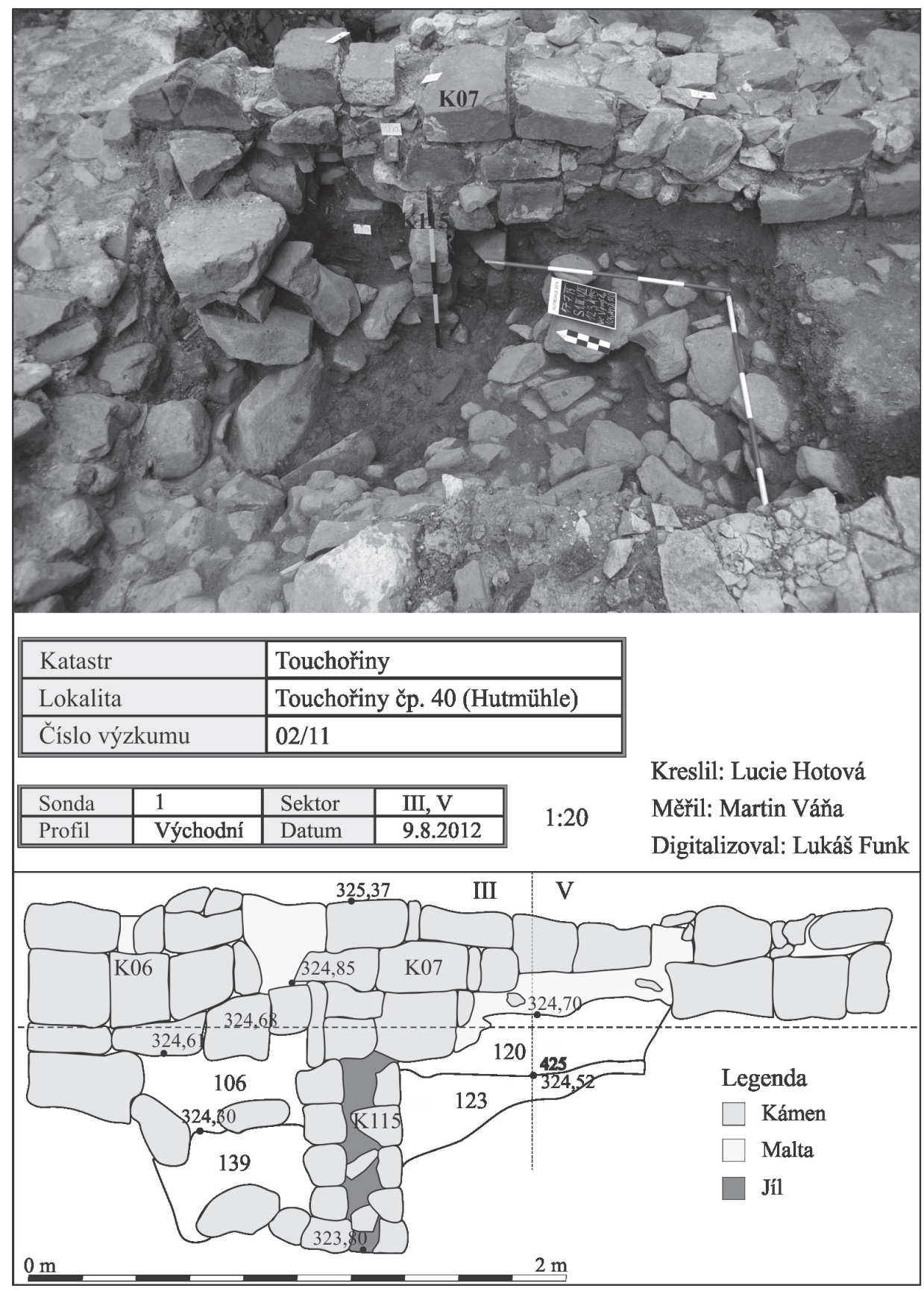

Obr. 13. Touchořiny čp. 40 (okres Litoměřice). Sonda 1, sektor III a V. Konstrukci K115 překryla novověká konstrukce K07 (foto a digitalizace L. Galusová, 2014, 2015). 
tohoto rodu byl mlýn modernizován. Vodní kolo však zůstalo zachováno minimálně do roku 1930 (Seznam a mapa... 1932b, sešit 10: 31). Objekt nejpozději v průběhu první poloviny 20 . století dosáhl rozměru 13,8 x $25 \mathrm{~m}$. Mlýnice se síní byly vybaveny střechou, krytou šindelem. Ve 20. století byla již stavba zbudována z kamene a cihel, jak napovídá mocná cihlovo-kamenná destrukce a fotografie vodního mlýna z průběhu první poloviny 20. století (patrně 20.-30. léta). Fotografie, tak jako její kresebná rekonstrukce zřetelně naznačuje soudku mezi vodním mlýnem (nalevo) vymezeným K406 a severním přístavkem (napravo) vymezeným konstrukcí K02.

Mlýn v průběhu druhé poloviny 20. století zbourán těžkou technikou.

\section{ZÁVĚR}

Vzhledem k charakteru a poloze vodních mlýnů provázejí bádání interpretační nesnáze, a to především u objektů zaniklých již v průběhu středověku a novověku. Nedestruktivní výzkum a především odkryvy mlýništ' vzniknuvších v pozdním středověku až raném novověku zachovaných do současnosti nabídly poznání objektů od jejich nejmladších fází (pokud nebyly odstraněny) po ty nejstarší a tím i cenné srovnání s ostatními lokalitami.

$\mathrm{V}$ tomto smyslu je tak nejcennějším odkryv vodního mlýna Hutmühle (Touchořiny čp. 40), který byl také nejvíce publikován a jenž může být v kontextu dalších takovýchto budoucích výzkumů základem pro hlubší poznání mlýnů v Čechách.

Uvedené výzkumy mimo tyto možnosti však měly poukázat na vysoký potenciál dotčených mlýništ' a vůbec staveb zaniklých ve druhé polovině 20 . století a jejich vysokou památkovou hodnotu, která mnohdy není na první pohled zřejmá a dotčené stavby tak nejsou dostatečně chráněny. Současně byly nastíněny i významné limity těchto lokalit, které souvisí s jejich náročnými přestavbami v průběhu 20. století a způsobem likvidace, kdy docházelo k částečnému zastření starších situací a více či méně výrazné deformaci mladších zvrstvení a tedy tvorbě pseudokonstrukcí a inverzních stratigrafických jednotek, které samozřejmě někdy více, někdy méně, stěžují interpretaci. I přes veškeré uvedené limity však v sobě tyto stavby skrývají obrovský potenciál, který je třeba s rozmyslem a dostatečnou odborností těžit a zasazovat do celkového kontextu poznání vodních mlýnů v Čechách. 


\section{LITERATURA}

Ebel M. (2010), Archivní rešerše vodního mlýna Touchořiny čp. 40, uloženo v archivu SLA, Zubrnice.

Gabler H. (1993), Petlarn: eine Gemeinde im westlichen Egerland, Welsungen.

Galusová L. (2009), Zaniklá dila na vodní pohon jako objekty archeologického poznání, Diplomová práce, Katedra archeologie, FF ZČU, Plzeň.

Galusová L. (2010), Archeologický nedestruktivní výzkum vodních děl zaniklých po roce 1945, „Akta fakulty filozofické“ 4, pp. 280-302.

Galusová L. (2014), Vodni dila ve vesnickém prostředi vrcholného a pozdního středověku v Čechách: prostorové vazby a sídelní souvislosti, Disertační práce, Katedra archeologie, FF ZČU, Plzeň.

Galusová L. (2015a), Archeologický výzkum vodního mlýna Touchořiny čp. 40 (sezóna 2011-2014), „Archeologia technica“ 26, pp. 81-95.

Galusová L. (2015b), Vodní mlýn jako objekt archeologického výzkumu, „Archaeologia historica“ 40, pp. 267-293.

Galusová L. (2016), Keramická konvička nalezená na vodním mlýně Touchořiny čp. 40 a teorie o dětské kojenecké „,lahvi“, „Ústecký sborník historický“ 2016(1), pp. 57-67.

Galusová, L., Maříková, M. (2015), Die Baugestalt der Wassermühlen im mittelalterlichen Böhmen und Mähren, [in:] M. Maříková, Ch. Zschieschang (eds.), Wassermühlen und Wassernutzung im mittelalterlichen Ostmitteleuropa, (= Forschungen zur Geschichte und Kultur des östlichen Mitteleuropa, Band 50), Franz Steiner, Stuttgart, pp. 309-324.

Galusová L., Maříková M. (2016), Archaeology of Watermills in Bohemia, [in:] L. Jaccottey, G. Rollier (eds.), Archéologie des moulins hydrauliques, à traction animale et à vent des origines à l'époque médiévale/The Archaeology of Water-, Animal-and Wind-Powered Mills From their Origins to the Middle Ages, vol. II (= Annales littéraires des l'Université de Besançon), pp. 309-324.

Seznam a mapa... (1932a), Seznam a mapa vodních děl republiky Československé: Stav koncem roku 1930, Ministerstvo veřejných prací, Praha, Sešit 5, p. 39.

Seznam a mapa... (1932b), Seznam a mapa vodních děl republiky Československé: Stav koncem roku 1930, Ministerstvo veřejných prací, Praha, Sešit 10, p. 31.

Vařeka P. (2004), Archeologie středověkého domu I.: Proměny vesnického obydlí $v$ Evropě v průběhu staletí, Plzeň.

Vařeka P. (2010), Zaniklá středověká a raně novověká vesnice Vojkov na Černokostelecku-nedestruktivní výzkum, „Acta Fakulty filozofické Západočeské univerzity v Plzni“, pp. 147-182.

Vařeka P., Balý R., Funk L., Galusová L. (2008), Archeologický výzkum vesnic středověkého pưvodu na Tachovsku zaniklých po roce 1945, „Archaeologica historica“ 33, pp. 101-117.

Vojtíšek B., Vařeka J. (1999), Lidová architektura v severních Čechách, Česká Lípa. 


\section{SumMary}

\section{ARCHAEOLOGY OF MILLS WHICH CEASED OPERATIONS IN THE SECOND HALF OH THE 20TH CENTURY}

Case studies of watermills that ceased to exist during the 20th century, examined via archaeological methods in the regions of West and Northwest Bohemia, have brought significant findings in the form of particular building stages from the oldest times to the turn of the 19th and 20th centuries. The Watermill of Hutmühle (Litoměřice district, Northwest Bohemia, near the village of Zubrice) was the most thoroughly investigated site. In the scope of this archaeological excavation, various methodological differences, possibilities and limits of research of such sites appeared. Based on the scientific activities performed, it is evident that these watermills are highly valuable technical sights, which shall be paid more attention to in terms of both archaeological and historical monument care. 